\title{
Phynotypic and genotypic identification of Eimeria species in backyard chicken in Nineveh governorate, Iraq
}

\author{
A.M. Ahmed ${ }^{(}$and H.S. Albakri ${ }^{\circledR}$ \\ Department of Veterinary Microbiology, College of Veterinary Medicine, University of Mosul, Mosul, Iraq
}

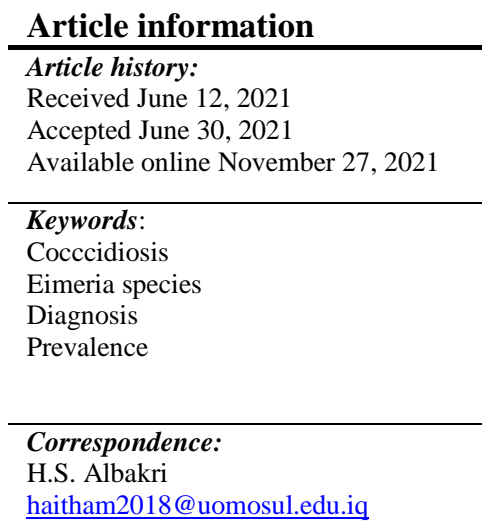

\begin{abstract}
Coccidiosis is an intestinal disease caused by a parasite of the genus Eimeria. This parasite mainly affects poultry species and causes great economic losses in the poultry industry. This study was designed to estimate the prevalence of coccidiosis in the local breed of domestic chicken in Nineveh Governorate, Iraq. 450 faecal swabs and intestinal samples (intestinal scraping) were collected from different local breeds of home-bred chickens from October 2020 to the end of March 2021. All fecal samples were examined using the flotation method by using sugar solution, and Eimeria was confirmed by the polymerase chain reaction method. Fecal examination results showed that $32.6 \%$ of the total samples were positive for Eimeria oocysts, classified into six species including $E$. brunetti, E. mitis.E. maxima E. acervulina E. necatrix, E. tenella with infection rates are $57.5,44.2,42.1,26.5,20.4,16.3 \%$, respectively. The phenotypic results were genetically confirmed by the result of the reaction of 455 base pairs. The prevalence of coccidiosis was highest in chickens less than three months of age $49.2 \%$ and lowest in chickens older than 6 months $23.9 \%$.
\end{abstract}

DOI: $10.33899 /$ ijvs.2021.130487.1834, (CAuthors, 2021, College of Veterinary Medicine, University of Mosul.

This is an open access article under the CC BY 4.0 license (http://creativecommons.org/licenses/by/4.0/).

\section{Introduction}

There are many parasitic diseases, which affect in backyard poultry which are due to poor management (1). Avian coccidiosis is enteric disease caused by protozoan parasite of the genus Eimeria phylum Apicomplex caused significant economic losses in poultry industry worldwide which annually estimated about three billion dollars due to of high incidence of morbidity and mortality lead to low productivity, lack of growth, animal death, costs of treatment and disease control (2).

The disease occurs associated with poor management by ingestion the sporulated oocysts of contaminated food and water (3). The disease clinically characterized by diarrhea develop to bloody diarrhea due to acute intestinal inflammation and, low feed conversion rate, poor growth, low production, and high morbidity and mortality.
In poultry there are seven important species belonges to genus Eimeria (E. brunetti, E. maxima, E. necatrix, E. tenella, E. mitis, E. acervulina and E. praecox) characterized by high degrees of host and site specificity (4). For example, E. tenella consider to be most pathogenic and wide spread in chicken compared with other species in Poultry (5). Phenotypically there are different criteria used previously for identification and characterization of Eimeria species such as parasitized intestine zone, gross appearance of the lesion, oocyst morphology, minimum sporulation period, minimum prepatent time, parasite location in the intestinal epithelium, and crossimmunization tests $(6,7)$.

The present study was designed to estimate the prevalence of coccidiosis in local breed of backyard chicken in Nineveh governorate, Iraq using phenotypic (morphological) and genotypic (PCR) methods to identify the species and genus of Eimeria. 
Iraqi Journal of Veterinary Sciences, Vol. 35, Supplement II, 2021 (41-46)

Proceedings of the 3rd National (1 st International) Conference of Biology,

College of Education for Pure Science, University of Mosul

\section{Materials and methods}

\section{Sample collection}

A total of 450 samples of fresh fecal swabs $(n=390)$ and intestine contain (intestinal scraping smear) $(n=60)$ were collected randomly from backyard chicken from different locations in Nineveh governorate, Iraq. The study was conducted from October 2020 to March 2021. Fresh fecal samples were collected using spatula and preserved in a clean polypropylene tube. The samples were labelled with the name of farm (owner), location of the farm, date of collection, and health status. Samples were transported to the laboratory of Department of Microbiology, University of Mosul, Mosul, Iraq and kept in $4^{\circ} \mathrm{C}$ until further analysis.

\section{Phenotypic (morphological) examination}

Microscopic identification of Eimeria spp in the present study was based on following criteria: size (length and width $\mu \mathrm{m} / \mu \mathrm{m}$ ) and shape of oocyst, presence or absence of micropyle, sporulation time and location of lesion in the gut. The intestine (duodenum, jejunum, ileum, large intestine: caeca) was opened and gross examination of pathological lesions were recorded and sample was scraped. All fecal swabs and intestinal content samples were examined microscopically by simple floatation technique using saturated sugar solution as described by Urquhart et al. (8). Of each sample 25 oocytes at least were examined morphometrically and oocyst was measured (length and width $\mu \mathrm{m} / \mu \mathrm{m}$ ) using calibrated ocular microscope at X40 magnification (9).

The statistical analysis of oocytes measurements of size (length and width $\mu \mathrm{m} / \mu \mathrm{m}$ ) were analyzed using the Ocular Micrometer under the magnification power of $40 \mathrm{x}$ and the true dimensions of the egg sack were found according to the following equation: true egg sac dimensions = measurement of egg sac dimensions in the planned eyepiece $\times$ microscope factor (6).

\section{Sporulation of parasite}

Oocyst were diluted into $2.5 \%$ aqueous potassium dichromate and kept in Petri dishes for sporulation using shaker water bath at $29^{\circ} \mathrm{C}$. The dichromate solution $2.5 \%$ was used to provide sufficient moisture and destroyed other bacteria. After sporulation, oocysts were recovered by centrifugation with saturated sugar solution as described by Duszynski and Wilber (10) and used in subsequent analysis. Microscopic examination was performed at various times to determine the sporulation of oocysts (4). The shape (length/width) of the sporulated oocysts were determined by using the method for species identification as described by Hadipour et al. (11). The calculated oocysts shape index values were then compared with the standard diagnostic guide provided by Teixeira and Lopes (12) to determine the species encountered in the study.

\section{Nucleic acid extraction}

DNA was extracted from oocysts of Eimeria spp using QIAamp fast DNA Stool Mini Kit in accordance with the recommended procedure of manufacturer (Qiagen, Hilden, Germany as following. A total of $220 \mu \mathrm{g}$ of fresh feces was initially suspended in $1 \mathrm{~mL}$ inhibit buffer (Qiagen) and incubated for $5 \mathrm{~min}$ at $70^{\circ} \mathrm{C}$ with vortexed intervals for $15 \mathrm{~s}$. The suspension was centrifuged at $900 \times \mathrm{g}$ for $1 \mathrm{~min}$ and 200 $\mu \mathrm{L}$ of supernatant was transferred in to $1.5 \mathrm{~mL}$ Eppendorf tubes. Afterwards, proteinase $\mathrm{K}(15 \mu \mathrm{L})$ and $200 \mathrm{AL}$ lysis buffer (Qiagen, Hilden, Germany) were added and the suspension was incubated at $70^{\circ} \mathrm{C}$ for $10 \mathrm{~min}$. This was then heated at $70^{\circ} \mathrm{C}$ for $10 \mathrm{~min}$, then $200 \mu \mathrm{L}$ of absolute ethanol was added and vortexed. Final suspension was treated with spin column (Qiagen) following the manufacturer's instructions. The purified DNA was quantified using NanoDrop (Thermo Fisher Scientific, Darmstadt, Germany).

\section{Eimeria-based PCR assay}

The DNA was further confirmed by protocol targeting of the 18S rRNA gene using universal PCR primers (Forward primer: CGCGCAAATTACCCAATGAA and revers primer: ATGCCCCCAACTGTCCCTAT) (13) resulting in an amplicon of $\sim 455$ base pairs. The gDNA was used as template for PCR amplification. Each $20 \mu \mathrm{L}$ PCR reaction mixture comprised of $2 \mu \mathrm{L}$ gDNA, $1 \mu \mathrm{L}$ of each forward and reverse primer $10 \mathrm{pM}, 10 \mu \mathrm{L}$ Master Mix and $6 \mu \mathrm{L}$ aqua dest. PCR amplification cycles were: initial denaturation at $95^{\circ} \mathrm{C}$ for $10 \mathrm{~min}$, followed by 35 cycles of $95^{\circ} \mathrm{C}$ for $45 \mathrm{~s}, 65^{\circ} \mathrm{C}$ for $10 \mathrm{~s}$ and $72^{\circ} \mathrm{C}$ for $12 \mathrm{~s}$, and a final extension at $72^{\circ} \mathrm{C}$ for $40 \mathrm{~s}$. The amplified PCR products were electrophoresed on 1.5 agarose gel matrix, stained in ethidium bromide $0.5 \mu \mathrm{g} \mathrm{mL}^{-1}$ and visualized at $302 \mathrm{~nm}$ on a UV transilluminator using the Geldoc 2000 gel documentation system (BioRad, Munich, Germany).

\section{Results}

A total of 147 (32.6\%) from 450 fecal and intestinal contain samples were phenotypically positive of Eimeria spp oocysts. The highest prevalence rate was recorded March and lowest was in October with significant difference (Table 1). Six different Eimeria species were recorded including: E. tenella $57.5 \%$, E. necatrix $44.2 \%, E$. acervulina $42.1 \%$, E. maxima $26.5 \%$, E. mitis $20.4 \%$ and $E$. brunetti $16.3 \%$, respectively (Table 2). Mixed infection with more than two species of Eimeria was recorded. Morphological Characterization of oocysts of sporulated and nonsporulated oocyst was illustrated in (Fiqure1-6). The prevalence rate was higher in chicken of age $<3$ month and lower in chicken of age $>6$ months (Table 3 ).

According to the clinical signs the prevalence rate of Eimeria oocytes were observed in Backyard chicken was 
Iraqi Journal of Veterinary Sciences, Vol. 35, Supplement II, 2021 (41-46)

Proceedings of the 3rd National (1 st International) Conference of Biology,

College of Education for Pure Science, University of Mosul

clinically healthy and no signs of disease were recorded (Table 4). The sporulation time was recorded as following: E. maxima after $30 \mathrm{~h}$, E. mitis and E. acervulina after $18 \mathrm{~h}$ and E. necatrix, E. tenella, E. brunetti after $20 \mathrm{~h}$. and the morphometric form of Eimeria oocyst (Table 5). The of molecular results revealed that all the samples investigated in the present study showed amplification size $455 \mathrm{bp}$ of genus Eimeria which was considered positive PCR reaction (Figures 1-7).

Table 1: Distribution of positive Eimeria oocyst in backyard chicken in the present study

\begin{tabular}{ccc}
\hline Periods & Number & Number $(\%)$ of positive \\
\hline 10.2020 & 85 & $20(23.5)$ \\
11.2020 & 75 & $30(40)$ \\
12.2020 & 65 & $17(26.1)$ \\
01.2021 & 70 & $16(22.8)$ \\
02.2021 & 80 & $29(36.25)$ \\
03.2021 & 75 & $35(46.6)$ \\
\hline Total & 450 & $147(32.6)$ \\
\hline
\end{tabular}

Table 2: Percentage of six Eimeria species identified backyard chicken in the present study

\begin{tabular}{lc}
\hline Species & Number (\%) of positive samples \\
\hline E. tenella & $84(57.5)$ \\
E. necatrix & $65(44.2)$ \\
E. acervulina & $62(42.2)$ \\
E. maxima & $39(26.5)$ \\
E. mitis & $30(20.4)$ \\
E. brunetti & $24(16.3)$ \\
\hline
\end{tabular}

Table 3: Distribution of coccidiosis according to the age of backyard chicken investigated in the present study

\begin{tabular}{lcc}
\hline \multirow{2}{*}{ Age of chicken } & \multicolumn{2}{c}{ Number $(\%)$} \\
\cline { 2 - 3 } & examined samples & +ve samples \\
\hline$>3$ months & 126 & $62(49.2)$ \\
$3-6$ months & 119 & $36(30.2)$ \\
< 6 months & 205 & $49(23.9)$ \\
\hline Total & 450 & $147(32.6)$ \\
\hline
\end{tabular}

Table 4: Prevalence of coccidiosis in backyard chicken according to clinical signs

\begin{tabular}{|c|c|c|c|c|c|c|}
\hline Eimeria & $\begin{array}{c}\text { Oocyst } \\
\text { size }(\mu \mathrm{m})\end{array}$ & $\begin{array}{l}\text { Mean of Width } \\
\text { and length }(\mu \mathrm{m})\end{array}$ & $\begin{array}{l}\text { Sporulation } \\
\text { time (h.) }\end{array}$ & Morphology & $\begin{array}{c}\text { Site of } \\
\text { infection }\end{array}$ & Gross lesion \\
\hline E. tenella & $\begin{array}{c}19.57 \times 22 \\
5\end{array}$ & $17-22 \times 25.5-20$ & 20 & $\begin{array}{l}\text { Ovoid, thin } \\
\text { smooth wall }\end{array}$ & Caecum & $\begin{array}{l}\text { Hemorrhagic and filled } \\
\text { with clotted and } \\
\text { unclotted blood }\end{array}$ \\
\hline E. necatrix & $16.7 \times 19.1$ & $\begin{array}{c}12.5-18 \times 22.5- \\
14\end{array}$ & 20 & $\begin{array}{l}\text { oblong ovoid, } \\
\text { thin wall }\end{array}$ & Jejunum & $\begin{array}{l}\text { Petechial hemorrhage and } \\
\text { mucoid }\end{array}$ \\
\hline E. acervulina & $\begin{array}{c}15.23 \times 19 \\
2\end{array}$ & $\begin{array}{c}17.9-21.5 \times \\
14.2-16\end{array}$ & 18 & $\begin{array}{l}\text { Ovoid, thin } \\
\text { smooth wall } \\
\text { narrow } \\
\text { anterior end }\end{array}$ & Duodenum & $\begin{array}{c}\text { Congestion and } \\
\text { thickening of mucosa } \\
\text { with whitish transverse } \\
\text { lesion }\end{array}$ \\
\hline E. brunetti & $\begin{array}{c}19.74 \times 23 \\
4\end{array}$ & $\begin{array}{c}21-28.2 \times 18.5- \\
22\end{array}$ & 20 & $\begin{array}{l}\text { Ovoid, thick, } \\
\text { brown wall }\end{array}$ & Ileum & $\begin{array}{l}\text { Mucoid content and } \\
\text { thickening of mucosa }\end{array}$ \\
\hline E. maxima & $\begin{array}{c}22.3 \times \\
28.5\end{array}$ & $23-30.5 \times 18-24$ & 30 & $\begin{array}{l}\text { Large ovoid, } \\
\text { thick wall, } \\
\text { yellow- brown }\end{array}$ & $\begin{array}{c}\text { Jejunum } \\
\text { and Ileum }\end{array}$ & $\begin{array}{l}\text { Petechial hemorrhage and } \\
\text { thickening of intestinal } \\
\text { wall }\end{array}$ \\
\hline E. mitis & $14.7 \times 15$ & $\begin{array}{c}11.5-17.5 \times \\
12.5-18\end{array}$ & 18 & $\begin{array}{l}\text { Sub spherical, } \\
\text { thin wall }\end{array}$ & Ileum & Enteritis \\
\hline
\end{tabular}

Table 5: Morphological and morphometric characterization of Eimeria species in backyard chicken

\begin{tabular}{lcc}
\hline Diarrhea & No. examined & No. $(\%)$ positive \\
\hline Without diarrhea & 334 & $121(36.22)$ \\
With diarrhea & 116 & $26(22.41)$ \\
\hline Total & 450 & $147(32.6)$ \\
\hline
\end{tabular}

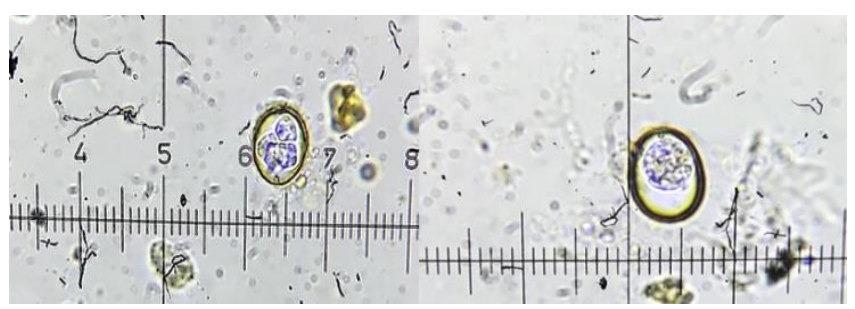

Figure 1: Sporulated and nonsporulated oocyst of E. tenella (40X). 
Iraqi Journal of Veterinary Sciences, Vol. 35, Supplement II, 2021 (41-46)

Proceedings of the 3rd National (1 st International) Conference of Biology, College of Education for Pure Science, University of Mosul

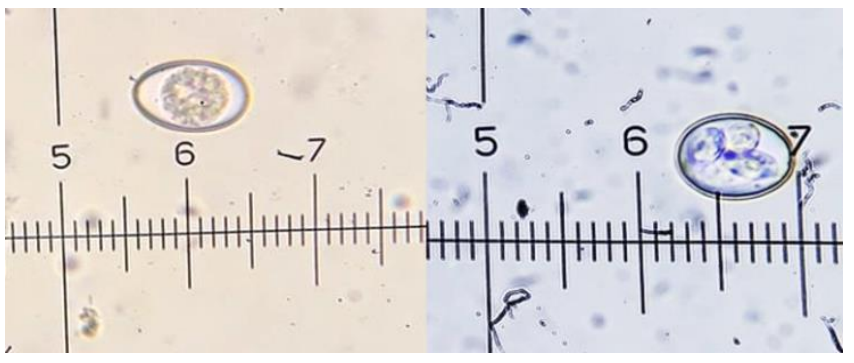

Figure 2: Oocyst of E. acervulina (40X).



Figure 3: Oocyst of E. necatrix (40X).



Figure 4: Oocyst of E. mitis (40X).

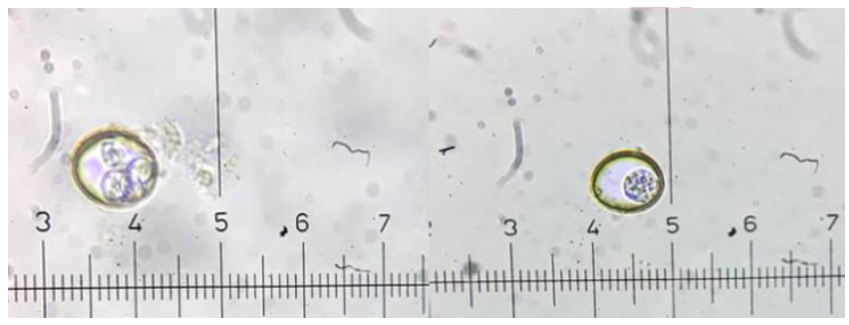

Figure 5: Oocyst of E. brunetti (40X).

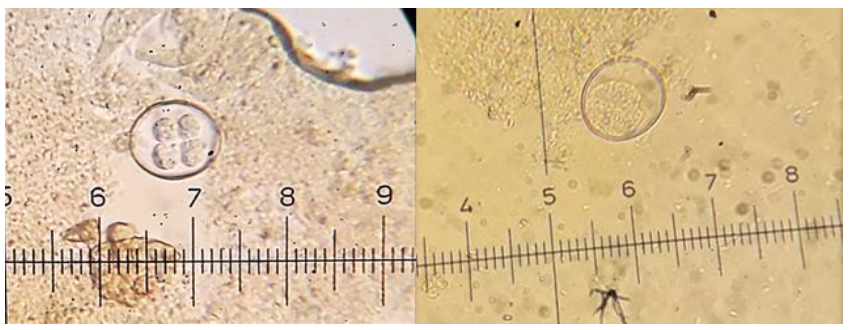

Figure 6: Oocyst of E. maxima (40X).

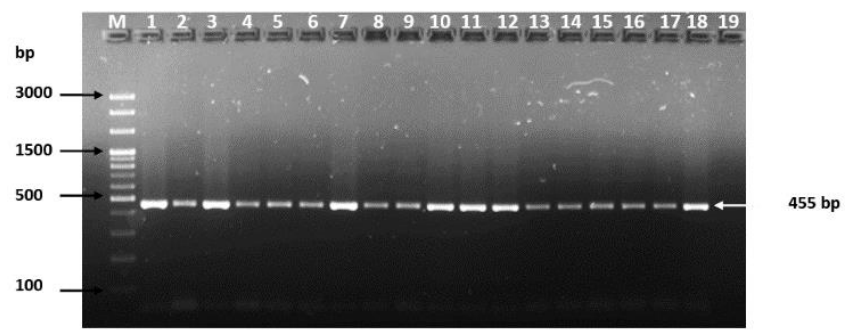

Figure 7: Agarose gel electrophoresis of 18S rRNA gene of genus Eimeria showing amplification product size ca. 455 bp. M: Marker 100 bp. Wells 1-18 are positive samples, well 19 is negative control.

\section{Discussion}

In present study the prevalence of coccidiosis in local breed of backyard chicken was $32.6 \%$, the result was agreement with Kabouudi et al. (14) and Nnadi and George (15) were recorded $31.8 \%$ and $35.5 \%$ of coccidiosis in local breed chicken in Tunisia and Nigeria (11), respectively. In Turkey (16), in Ethiopia and in Egypt (17) were recorded the coccidiosis in $54.3 \%, 64 \%, 53.6 \%$ and $21.24 \%$ in chicken. These differences in prevalence rates could be attributed to the conditions of breeding, the study area, the efforts made to control the disease, the different climatic and environmental conditions from one region to another, the season of sample collection during the year, in addition to the difference in the number of samples examined and the ages of the chickens examined (18). Diarrhea is a major clinical sign of coccidiosis in the chicken (19) and it is worth mentioning the prevalence of subclinical coccidiosis in backyard chicken in the present study was significantly higher than clinical coccidiosis which considered as carrier of oocyst without showing any signs of disease. Previous studies also mentioned that subclinical coccidiosis in local breed chicken are most prevalent and acting a source of infection and also effect on production performance of chicken (20). This attributed to repeated exposure to different species of Eimeria and development of immunity against the parasite. These birds are become a source of oocyst fecal shedding and lead to contaminate of surrounding farm environment (e.g. housing surfaces, pasture, water, feed, soil, and more others). In the present study six Eimeria species were identified and this species were recorded also previously (21). The most prevalent species was E. tenella $57.5 \%$ which agreement with other previous studies $(5,15,22)$. But other previously study reported that $E$. acervulina, and $E$. tenella are most prevalent species (23). In the present study mixed infection with more than two Eimeria species was observed in local breed chicken as reported previously (24). In the present study, the age of local breed of chicken was studied as one 
Iraqi Journal of Veterinary Sciences, Vol. 35, Supplement II, 2021 (41-46)

Proceedings of the 3rd National (1 st International) Conference of Biology,

College of Education for Pure Science, University of Mosul

of the main factors in the incidence and spread of coccidiosis in poultry, but Eimeria species can be infected all live of bird in different ages (25). The higher prevalence of coccidiosis in young chicken 0-3 months compare with chicken $>6$ months this result was agreement with Wondimu et al. (26) who reported high incidence of coccidiosis in young bird. Highest prevalence rate of infection recorded in March while lowest infection rate was in October. This may be attributed to the relative moderation of temperatures in this month, with the presence of humidity and rainfall that provides adequate conditions for the sporulation of Eimeria oocyst and occurrence of infection. The morphology of oocyst and sporulation time and gross lesion may help in identification of Eimeria species in present study oocyst length, width and morphology were an indicative for Eimeria species identification. Most of Eimeria oocysts were identified in ovoid shape which agreement with Soulsby (9) which reported the length and width of E. tenella was 19.5-26 and $16.5-22.8 \mu \mathrm{m}(20,26)$ were reported that length and width E. acervulina $15.7-20.3$ and 14.5- $18.6 \mu \mathrm{m}$ and E. maxima 27.9-34.5 and 18.6-26.4 $\mu \mathrm{m}$ and E. brunetti 20.6-26.3 and $16.9-21.6 \mu \mathrm{m}$.

\section{Conclusion}

This study demonstration the Eimeria species parasite in digestive system of backyard chicken by using microscopy and nested PCR.

\section{Acknowledgments}

The authors thanks to College of Veterinary Medicine, University of Mosul to supports this research.

\section{Conflicts of Interest}

The authors declare that there are no conflicts of interest regarding the publication of this manuscript.

\section{References}

1. Mohammad ZA. Some chewing lice (Phthiraptera) species as ectoparasites infested aquatic birds with a new record of three species from Al-Sanaf marsh/southern Iraq. Iraqi J Vet Sci. 2020;34(1):173180. DOI: 10.33899/ijvs.2019.125721.1139

2. Dalloul RA, Lillehoj HS. Poultry coccidiosis: Recent advancements in control measures and vaccine development. Expert Rev Vaccines. 2006;5(1):143-163. DOI: $10.1586 / 14760584.5 .1 .143$

3. Shahraki F, Shariati-Sharifi R, Jamshidian A. Coccidiosis in Sistan: the prevalence of Eimeria species in native chicken and its histopathological changes. Comp Clin Pathol. 2018;27(6):1537-1543. DOI: $10.1007 / \mathrm{s} 00580-018-2770-\mathrm{x}$

4. Fatoba AJ, Adeleke MA. Diagnosis and control of chicken coccidiosis: A recent update. J Parasit Dis. 2018;42(4):483-493. DOI: 10.1007/s12639-018-1048-1

5. Awais MM, Akhtar Z, Iqbal F, Muhammad A, Anwar MI. Seasonal prevalence of coccidiosis in industrial broiler chickens in Faisalabad,
Punjab, Pakistan. Trop Anim Hlth Prod. 2012; 44(2):323-8 DOI: 10.1007/s11250-011-0024-X

6. Al-Taee AF. Incidence of broiler caecal coccidiosis in Ninevah Governorate 1999-2004. Iraqi J Vet Sci. 2007;21(1):45-63.

7. DOI: $10.33899 /$ ijvs.2007.5610

8. Conway DP, McKenzie ME. Poultry coccidiosis diagnostic and testing procedures. $3^{\text {rd }}$ ed. Iowa: Blackwell publishing; 2007. 1-162 p.

9. Urquhart GM, Armour J, Duncan JL, Dunn AM, Jennings FW. Veterinary Parasitology. $3^{\text {rd }}$ ed. New York: CRB Press; 2003. 223-231 p.

10. Soulsby EJ. Coccidiosis of domestic fowl. $7^{\text {th }}$ ed. London: Bailliere, 167-169 p.

11. Duszynski DW, Wilber PG. A guideline for the preparation of species descriptions in the Eimeriidae. J Parasitol. 1997;83:333-336.

12. Hadipour MM, Olyaie A, Nader M, Azad F, Nekouie O. Prevalence of Eimeria species in scavenging native chickens of Shiraz, Iran. African J Microbiol Res. 2011;5(20):3296-3299. DOI: 10.5897/AJMR11.477

13. Teixeira M, Lopes CW. Species of the genus Eimeria (Apicomplexa: Eimeriidae) from Japanese quails (Coturnix japonica) in Brazil and Eimeria fluminensis for the preoccupied Eimeria minima of this quail. 2002;9:53-56. DOI: 10.1007/s00436-017-5602-Z

14. Hinsu AT, Thakkar JR, Koringa PG, Vrba V, Jakhesara SJ, Psifid A, Blake DP. Illumina next generation sequencing for the analysis of Eimeria populations in commercial broilers and indigenous chickens. Frontiers Vet sci. 2018;5:176. DOI: $10.3389 /$ fvets.2018.00176

15. Kaboudi K, Umar S, Munir MT. Prevalence of coccidiosis in freerange chicken in Sidi Thabet, Tunisia. Scientifica. 2016. DOI: 10.1155/2016/7075195

16. Nnadi PA, George SO. A cross-sectional survey on parasites of chickens in selected villages in the subhumid zones of South-Eastern Nigeria. J Parasitol Research. 2010;2010:141824. DOI: 10.1155/2010/141824

17. Harper CK, Penzhorn BL. Occurrence and diversity of coccidia in indigenous, Saanen and crossbred goats in South Africa. Vet Parasitol. 1999;82:1-9. [available at]

18. Karaer Z, Guven E, Akcay A, Kar S, Nalbantoglu S, Cakmak A. Prevalence of subclinical coccidiosis in broiler farms in Turkey. Trop Anim Hlth Product. 2012;44(3):589-594. DOI: 10.1007/s11250-0119940-Z

19. Alene B, Temesgen W, Abebaw M, Negash A, Demelash K, Zemene M, Girma G. Study of the prevalence, species identification and risk factors associated with poultry coccidiosis in Gondar Town, North Ethiopia. 2016;14(9)

20. Melkamu S, Chanie M, Asrat M. Studies on coccidia in experimental infection with Eimeria spp in Rose-Cobb broiler chicken. J Anim Sci. 2017;7:115-22. DOI: 10.5958/2277-940X.2017.00016.X

21. Gharekhani Z. Sadeghi D, Bahrami M. Prevalence of coccidiosis in broiler chicken farms in Western Iran. J Vet Med. 2014;ID 980604:14. DOI: $10.1155 / 2014 / 980604$

22. Molla W, Teshome D, Almaw G, Temesgen W, Alemu S. Poultry coccidial infection in local chicken from three selected districts of North Gondar Zone, Ethiopia. Ethiopian Vet J. 2015;19(1):1-9. DOI: 10.4314/evj. v19i1.4

23. Hamid PH, Kristianingrum YP, Wardhana AH, Prastowo S, Silva LD. Chicken coccidiosis in Central Java, Indonesia: A recent update. Vet Med Inter. 2018. DOI: 10.1155/2018/8515812

24. Ashenafi H, Tadesse S, Medhin G, Tibbo M. Study on coccidiosis of scavenging indigenous chickens in central Ethiopia. Trop Anim Hlth Prod. 2004;36:693-701. DOI: 10.1023/b:trop.0000042852.82477.af

25. Ahmed AA, Olfat AM, Aida ANE, Mohamed SA. Studies on coccidia of Egyptian Balady breed chickens. Life Sci J. 2012; 9(3):568-576.

26. Tadesse, T, Teshome L. A study on copro-epidemiology of poultry coccidiosis in and around Jimma Town, Oromia Regional State, Ethiopia. J Vet Med Res. 2018. [available at] 
Iraqi Journal of Veterinary Sciences, Vol. 35, Supplement II, 2021 (41-46)

Proceedings of the 3rd National (1 st International) Conference of Biology,

College of Education for Pure Science, University of Mosul

اقتصادية كبيرة في صناعة الدو اجن. صمدت هذه الدراسة لتقدير نسبة

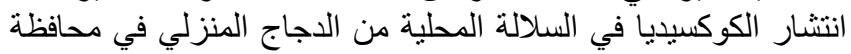

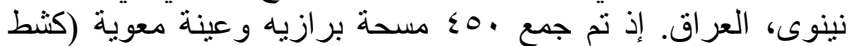

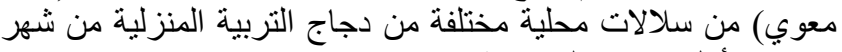

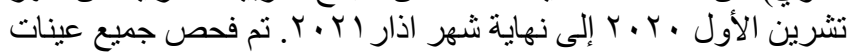

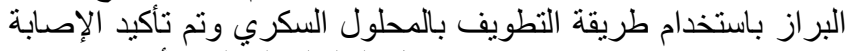

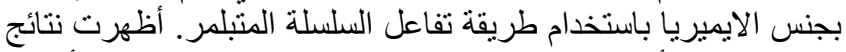

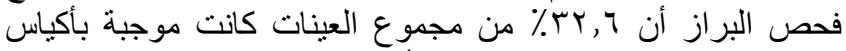

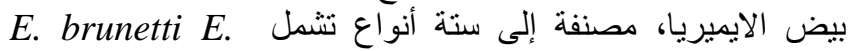
mitis.E. maxima E. acervulina E. necatrix, E. tenella

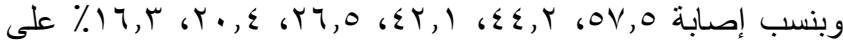

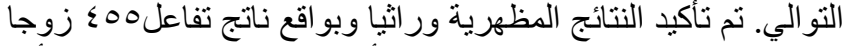

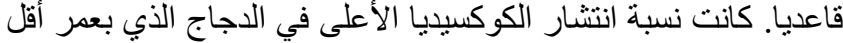

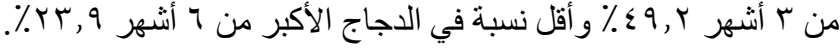

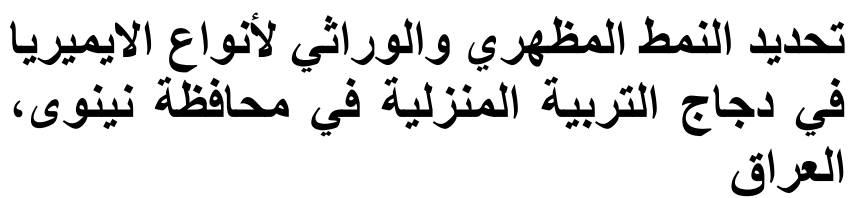

عدنان محمد أحمد و هيثم صديق البكري

فرع الأحياء المجهرية، كلية الطب البيطري، جامعة الموصل،

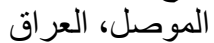

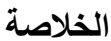

يعد داء الكوكسيديا مرضا معويا يسبيه طفيلي يعود لجنس الايميريا

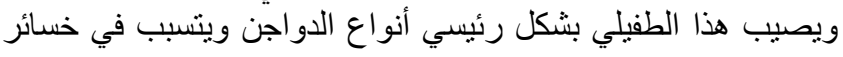

